\title{
On the status of early Eucricetodontinae (Muroidea, Rodentia) with a special focus on the Atavocricetodon vs Eucricetodon issue: morphometrical and microstructural aspects
}

\author{
Helder GOMES RODRIGUES ${ }^{1,2^{*}}$, Laurent MARIVAUX ${ }^{1}$ \& Monique VIANEY-LIAUD
}

${ }^{1}$ Laboratoire de Paléontologie, Institut des Sciences de 1'Évolution (UMR-CNRS 5554), Université Montpellier 2; cc 064, Place Eugène Bataillon; 34095 Montpellier Cedex 05, France; helder.gomes.rodrigues@ens-lyon.fr; Laurent.Marivaux@univmontp2.fr; monique.vianey-liaud@univ-montp2.fr

${ }^{2}$ Present address: Team “Evo-Devo of Vertebrate Dentition”, Institut de Génomique Fonctionnelle de Lyon, Université de Lyon, UMR 5242 CNRS UCBL ENS, Ecole Normale Supérieure de Lyon; 46 Allée d’Italie, 69364 Lyon Cedex 07, France

* Corresponding author

Gomes Rodrigues, H., Marivaux, L., \& Vianey-Liaud, M. 2013. On the status of early Eucricetodontinae (Muroidea, Rodentia) with a special focus on the Atavocricetodon vs Eucricetodon issue: morphometrical and microstructural aspects. [Sobre el estatus de los Eucricetodontinae tempranos (Muroidea, Rodentia) con un especial énfasis en la cuestión Atavocricetodon vs Eucricetodon: aspectos morfométricos y microestructurales]. Spanish Journal of Palaeontology, 28 (1), 17-28.

Manuscript received 4 May 2012

Manuscript accepted 15 October 2012

(C) Sociedad Española de Paleontología ISSN 2255-0550

ABSTRACT

Among the flourishing Muroidea, the Eucricetodontinae constitute the most diversified subfamily of the Eurasian Palaeogene. Early representatives, such as Atavocricetodon and Eucricetodon, are notably characterized by their simple and primitive dental morphology. As a result, it appears very difficult to discriminate these genera according to their dental morphology, and that is emphasized by their imprecise diagnosis. Here, we aim at challenging the taxonomic validity of Atavocricetodon, frequently considered as a grade of Eucricetodon. We chose to investigate the outline of first upper molars for four species of Atavocricetodon and seven of Eucricetodon, to avoid confusions made by their occlusal dental characters. The outline analysis involves samples of ten molars, and was realized by using Elliptic Fourier Transforms. Incisor enamel microstructures were investigated as well in four species, because this dental character appears highly useful in rodents to solve taxonomic issues. Results revealed that if a significant difference exists between the

\section{RESUMEN}

Entre los florecientes Muroidea, los Eucricetodontinae constituyen la subfamilia más diversificada del Paleógeno euroasiático. Sus representantes tempranos, tales como Atavocricetodon y Eucricetodon, se caracterizan notablemente por su morfología dental simple y primitiva. Como resultado, parece muy difícil discriminar estos géneros en relación con su morfología dental, y eso queda enfatizado por su imprecisa diagnosis. Aquí, pretendemos desafiar la validez taxonómica de Atavocricetodon, frecuentemente considerado como un grado de Eucricetodon. Para evitar las confusiones debidas a sus caracteres dentales oclusales, elegimos investigar el contorno de los primeros molares superiores de cuatro especies de Atavocricetodon y siete de Eucricetodon. El análisis del contorno implica muestras de diez molares, y fue realizado por medio de Transformaciones Elípticas de Fourier. Las microestructuras del esmalte de los incisivos fueron investigadas también en cuatro especies porque este carácter dental parece muy útil para la resolución de cuestiones 
global dental shape of Atavocricetodon and Eucricetodon, outline morphospaces of the considered species generally overlap as displayed by the multivariate analysis and the hierarchical clustering. This is partly explained by the high intrageneric shape variation, which might correspond to different Oligocene lineages of Eucricetodontinae. Such variation is also due to Atavocricetodon paaliense, which could rather belong to another genus, the pseudocricetontine Kerosinia. More generally, there is no discrete character or real apomorphy which permits to distinguish these genera, because incisor enamel microstructure patterns are highly variable and a few types are shared by both genera. Atavocricetodon cannot thus be retained neither as a genus, nor as a morphosubgenus of Eucricetodon. Further studies, including much more fossil material, are needed to accurately identify the various lineages of Eucricetodon and to potentially define new genera on a fair basis.

Keywords: Rodents, molar, Palaeogene, outline analysis, enamel microstructure.

\section{INTRODUCTION}

Muroid rodents currently represent the most flourishing mammal superfamily (310 genera, 1517 species; Musser $\&$ Carleton, 2005). During the Palaeogene, the extinct Eucricetodontinae subfamily was the most diversified group of Muroidea. This Eurasian group is of great interest because it consists of widespread and generalist species which could be at the origin of most of current taxa, such as Eumuroida (e.g., rats, mice, hamsters, voles; Lazzari et al., 2008). To date, early representatives encompass at least the four following genera: Eocricetodon Wang, 2007, Oxynocricetodon Wang, 2007, Atavocricetodon Freudenthal, 1996, and Eucricetodon (Thaler, 1966).

Eocricetodon and Oxynocricetodon were strict Late Eocene Chinese genera (Wang, 2007). The Eurasian radiation of Eucricetodontinae really started from the Oligocene with the appearance of both Atavocricetodon and Eucricetodon. However, Eucricetodon was not found in Europe before the Late Oligocene (VianeyLiaud, 1972). This episode roughly coincides with the disappearance of Atavocricetodon in Eurasia. The last record of Eucricetodon is European, and dates from the Early Miocene (Hugueney, 1999). All these early forms present a simple and bunodont dental morphology, which can be considered as plesiomorphic. This observation represents the main issue for discriminating these genera between themselves and to find true apomorphies.

Originally, these genera were synonymized with taxonómicas en roedores. Los resultados revelaron que, aunque existen diferencias significativas entre la forma dental global de Atavocricetodon y Eucricetodon, los morfoespacios del contorno de las especies consideradas generalmente solapan tanto en ordenaciones multivariantes como en agrupaciones jerárquicas. Esto se explica parcialmente por la elevada variabilidad intragenérica en forma, la cual podría corresponder a diferentes linajes oligocenos de Eucricetodontinae. Tal variación también es debida a Atavocricetodon paaliense, el cual podría pertenecer a otro género, el pseudocricetontino Kerosinia. Más generalmente, no existe un carácter discreto o apomorfía real que permita distinguir estos géneros, porque los patrones de microestructura del esmalte de los incisivos son altamente variables y unos pocos tipos son compartidos por ambos géneros. Atavocricetodon no puede ser, por tanto, retenido ni como género ni como subgénero de Eucricetodon. Estudios adicionales, incluyendo mucho más material fósil, son necesarios para identificar adecuadamente los distintos linajes de Eucricetodon y potencialmente definir nuevos géneros.

Palabras clave: Roedores, molar, Paleógeno, análisis de contorno, microestructura del esmalte.
Eucricetodon (Thaler, 1966). Thaler (1966) first erected Eucricetodon as a subgenus of Cricetodon Schaub, 1925 to differentiate some Oligocene-Miocene lineages from exclusive Miocene species, considered as highly derived. He did not propose diagnosis for Eucricetodon, saying that it consisted of a heterogeneous group. Vianey-Liaud (1972) gave one of the first diagnoses for the genus Eucricetodon, including six species: E. atavus, E. huberi, E. quercyi $=$ E. dubius, E. praecursor, E. collatus, and E. huerzeleri, this latter considered to be separated from other species. On the basis of additional material and characters (e.g., incisor enamel ornamentation), Comte (1985) proposed to bring E. huerzeleri closer to the "atavus-collatus group", while he considered E. dubius as a probable immigrant in Europe. Then, Freudenthal (1996) decided to separate the Early Oligocene European "atavus-group" from the homogeneous "collatus-group", the "huerzeleri-group" and the "dubius-group" to erect the genus Atavocricetodon, on the basis of four new species described from the Lower Oligocene of Spain (Olalla 4A, Teruel). More recently, de Bruijn et al. (2003) doubted about the validity of Atavocricetodon saying that it is rather an evolutionary grade of Eucricetodon. The most recent definitions of Atavocricetodon and Eucricetodon are of Freudenthal (1996) and Dienemann (1987), respectively:

- Diagnosis of Atavocricetodon: "Eucricetodontinae of very small to medium size, with relatively low-crowned cheek teeth, with thin enamel, relatively small cusps, and long crests. Lower molars with or without hypoconid hind 
arm. $M_{1}$ with protoconid hind arm frequently connected to the metaconid. Upper molars generally with a posterior protolophule (= protolophule II, see Gomes Rodrigues et al., 2010) and an anterior metalophule (= metaloph connected to the anterior arm of hypocone). $M^{l}$ generally without a complete anterolophule. Old entoloph (= mure) on $M^{3}$ frequently present, or even complete, neo-entoloph (= endoloph) fully developed."

Emended diagnosis of Eucricetodon (translated from german): "Mostly middle-sized cricetids with bunodont enamel pattern. The predominantly voluminous main-cusps are usually not very accentuated and proceed on broad bases. The slim valleys are constricted by often massively protruding ridges."

The diagnosis of Atavocricetodon relies on the frequency of morphological characters of the occlusal dental surface, while Eucricetodon was defined according to its overall dental morphology (outline, global relief,...), and both clearly emphasize two way of thinking. Since Atavocricetodon was created, this diagnosis has never been emended. Most of the characters cited are applicable to Eucricetodon, and none of them constitute apormophy. The diagnosis of Eucricetodon has not been emended since the split with Atavocricetodon, either. The most obvious difference between them could be the smaller size of Atavocricetodon (de Bruijn et al., 2003). The enamel microstructure of lower incisors also provided crucial data on both genera. Kalthoff $(2000,2006)$ showed that Atavocricetodon and Eucricetodon species have different tree-dimensional arrangement of enamel (i.e., schmelzmuster). They respectively display uniserial type 1 and 4 . The type 1 is primitive as respect to type 4 , because it was present in stem Muroidea (Koenigswald \& Kalthoff, 2007), and that could corroborate the grade assumption concerning Atavocricetodon. The type 4 could correspond to an autapomorphic character, since it is only known in Eucricetodon. However, the debate still exists given that the enamel of only a few species was investigated, especially during the Early Oligocene. Such examples again show the difficulty of discriminating taxonomic units on the basis of obvious and invariant criterions.

Gomes Rodrigues et al. (2010) also discussed the validity of Eocricetodon and Oxynocricetodon. The first genus appears monophyletic, but it does not display any discrete character, which could discriminate it from Atavocricetodon, except a complete anterolophule on $\mathrm{M}^{1}$. The second one is paraphyletic, stem group of Atavocricetodon, but it differs in preserving a protolophule I on $\mathrm{M}^{1}$, a characteristic of basal Muroidea. Given the paucity of material concerning these Late Eocene genera, it seems difficult to more accurately investigate them at that time. At the opposite, Atavocricetodon and Eucricetodon are widely represented according to the high number of species and dental material available. As a result, we proposed here to study the global dental shape of different Eurasian species involving both genera, by means of outline analysis excluding the traditional listing of dental characters, to investigate the incisor enamel microstructure, and to discuss the taxonomical validity of Atavocricetodon.

\section{MATERIAL AND METHODS}

\subsection{Outline analysis}

Dental materials are housed in the collections of Vertebrate Paleontology of the University of Montpellier 2 (UM2, France) and of the Institute of Vertebrate Paleontology and Paleoanthropology of Beijing (IVPP, China; Table 1). The Atavocricetodon samples include three European species ( $A$. atavus, $A$. aff. nanus and $A$. cf. huberi), and the Asian $A$. paaliense. Surprisingly, this latter species present a lophodont pattern, as well as a strong and wide prelobe on $\mathrm{M}^{1}$ as Pseudocricedontinae. For this reason, Pseudocricetodon montalbanensis was added to draw comparisons with this species. Seven species of Eucricetodon were investigated. Four European species were considered ( $E$. huerzeleri, E. dubius, E. hesperius, $E$. aquitanicus), in addition to the three Asian (E. bagus, E. asiaticus, E. jilantaiensis). The wide spectrum of species for each genus, although not exhaustive, reflects their important Eurasian diversity through the Oligo-Miocene period (Fig. 1, Table 1).

The dental nomenclature used here follows the rodents' nomenclature defined by Wood \& Wilson (1936), slightly modified by Gomes Rodrigues et al. (2012). $\mathrm{M}^{\mathrm{n}}$ and $\mathrm{M}_{\mathrm{n}}$ respectively refer to the $\mathrm{n}^{\text {th }}$ upper and $\mathrm{n}^{\text {th }}$ lower molars. Each sample consists of ten $\mathrm{M}^{1}$, except for $A$. paaliense for which only seven teeth are available. Overall tooth shapes were investigated by using an outline analysis. By registering the relative size and position of each cusp, the outline analysis represents a suitable method to study the overall shape of the tooth. Fourier methods, notably Elliptic Fourier Transform (EFT), allow the description of complex outlines approximating them by a sum of trigonometric functions of decreasing wavelength (i.e., harmonics; Fig. 2). The $x$ and $y$ coordinates of 64 points equally spaced along the dental outline were calculated to quantitatively describe the shape of $\mathrm{M}^{1}$. We applied EFTs to these data using EFAwin software (Ferson et al., 1985), extracting Fourier coefficients from the original outline and normalizing these shape variables. This method considers the separate Fourier decomposition of the incremental change in the $x$ and $y$ coordinates as a function of the cumulative length along the outline (Kuhl \& Giardina, 1982). For EFT, any harmonic $n$ yields four fourier coefficients: $A_{n}$ and $B_{n}$ for $x$, and $C_{n}$ and $D_{n}$ for $y$, which all contribute to describe the initial outline. We retained the 


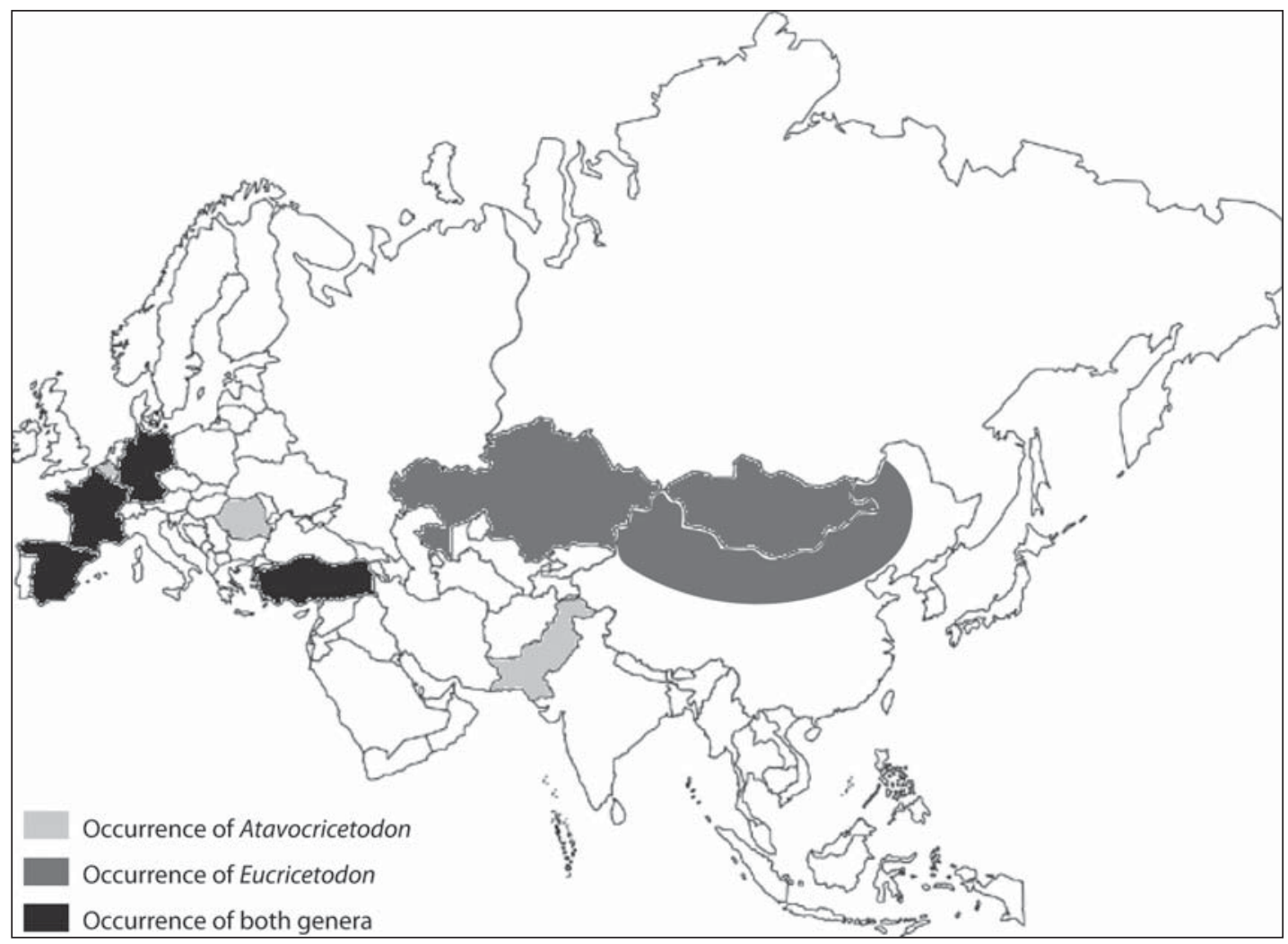

Figure 1. Map of Eurasia showing the main Oligo-Miocene areas where Atavocricetodon and Eucricetodon specimens were unearthed.

Table 1. Data concerning each species of Eucricetodon and Atavacricetodon investigated, in addition to Pseudocricetodon montalbanensis (N: number of specimens).

\begin{tabular}{|c|c|c|c|c|c|}
\hline Species & $\mathrm{N}$ & Age & Country & Locality & Collection \\
\hline $\begin{array}{l}\text { Atavocricetodon aff. nanus } \\
\text { Freudenthal, } 1996\end{array}$ & 10 & Early Oligocene (MP22) & France (Quercy) & Cavalé & UM2 \\
\hline $\begin{array}{l}\text { Atavocricetodon atavus } \\
\text { (Misonne, 1957) }\end{array}$ & 10 & Early Oligocene (MP23) & France (Quercy) & Itardies & UM2 \\
\hline $\begin{array}{l}\text { Atavocricetodon paaliense } \\
\text { Marivaux et al., } 1999\end{array}$ & 7 & Early Oligocene & Pakistan (Bugti Hills) & Paali Nala $\mathrm{C}_{2}$ & UM2 \\
\hline $\begin{array}{l}\text { Atavocricetodon cf. huberi } \\
\text { (Schaub, 1925) }\end{array}$ & 10 & Late Oligocene (MP25) & France (Quercy) & Belgarric 1 & UM2 \\
\hline $\begin{array}{l}\text { Eucricetodon huerzeleri } \\
\text { Vianey-Liaud, } 1972\end{array}$ & 10 & Late Oligocene (MP26) & France (Quercy) & Mas de Pauffié & UM2 \\
\hline $\begin{array}{l}\text { Eucricetodon dubius } \\
\text { (Schaub, 1925) }\end{array}$ & 10 & Late Oligocene (MP28) & France (Quercy) & Pech Desse & UM2 \\
\hline $\begin{array}{l}\text { Eucricetodon asiaticus } \\
\text { (Matthew \& Granger, 1923) }\end{array}$ & 10 & early Late Oligocene & China (Inner Mongolia) & $\begin{array}{c}\text { UTL4 } \\
\text { (Ulantatal) }\end{array}$ & IVPP \\
\hline $\begin{array}{l}\text { Eucricetodon jilantaiensis } \\
\text { Gomes Rodrigues et al., } 2012\end{array}$ & 10 & early Late Oligocene & China (Inner Mongolia) & $\begin{array}{c}\text { UTL4 } \\
\text { (Ulantatal) }\end{array}$ & IVPP \\
\hline $\begin{array}{l}\text { Eucricetodon bagus Gomes } \\
\text { Rodrigues et al., } 2012\end{array}$ & 10 & early Late Oligocene & China (Inner Mongolia) & $\begin{array}{c}\text { UTL4 } \\
\text { (Ulantatal) }\end{array}$ & IVPP \\
\hline $\begin{array}{l}\text { Eucricetodon hesperius } \\
\text { Engesser, } 1985\end{array}$ & 10 & Early Miocene (MN1) & France (Lot-et-Garonne) & Paulhiac & UM2 \\
\hline $\begin{array}{l}\text { Eucricetodon aquitanicus } \\
\text { Baudelot \& de Bonis, } 1968\end{array}$ & 10 & Early Miocene (MN3) & France (Herault) & Bouzigues & UM2 \\
\hline $\begin{array}{l}\text { Pseudocricetodon } \\
\text { montalbanensis Thaler, } 1969\end{array}$ & 10 & Early Oligocene (MP23) & France (Quercy) & Itardies & UM2 \\
\hline
\end{tabular}



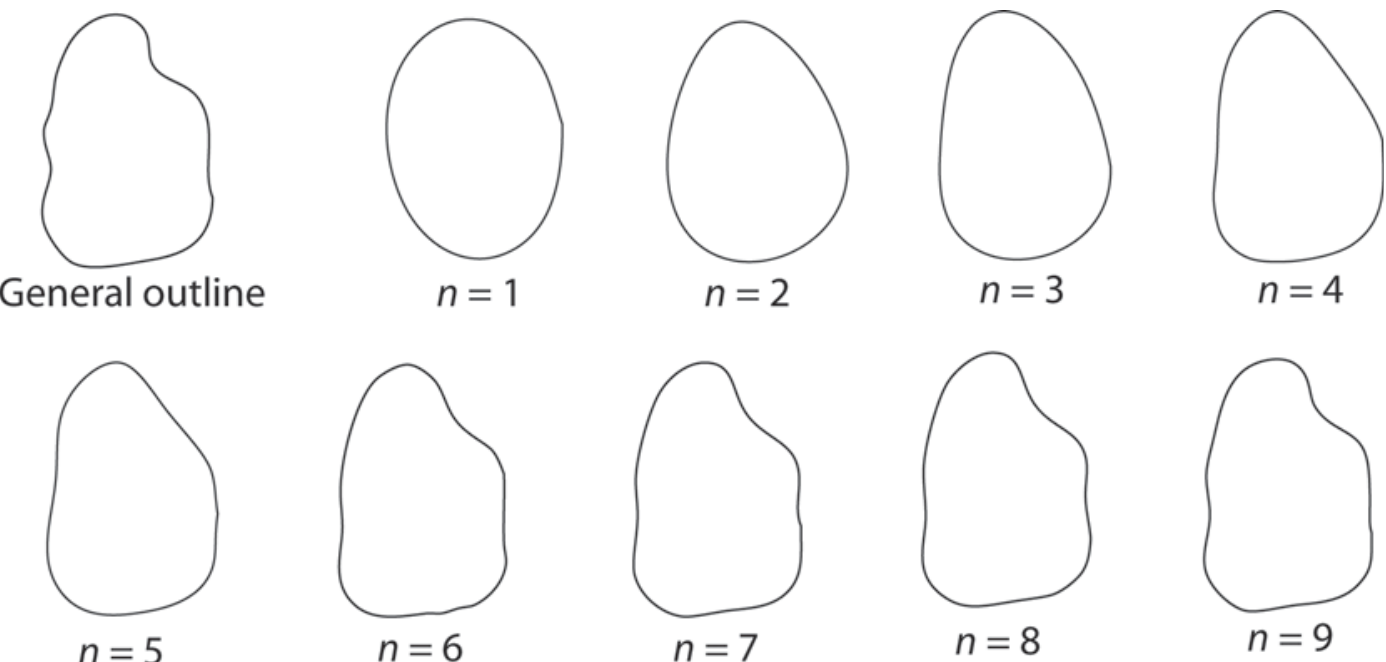

Figure 2. Description of $\mathrm{M}^{1}$ outline (e.g., E. asiaticus) according to the sum of $n$ harmonics.

first eight harmonics for the $\mathrm{M}^{1}$, which represents the best compromise between measurement error and information content for these muroid molars (Renaud et al., 1996). However, the four coefficients of the first harmonic ( $A 1-$ $D 1)$ were not included in the subsequent analyses, given that they are poorly discriminant and constitute background noise after the standardization step (size and orientation; Crampton, 1995; Renaud et al., 1996).

A principal component analysis (PCA) was performed to evaluate the morphospace of each species. Variables were represented by the 28 coefficients of each harmonics previously selected for $\mathrm{M}^{1}$. A multivariate analysis of variations (Manova) allowed researching a potential significant difference between the global morphospaces of Eucricetodon and Atavocricetodon. This analysis was coupled to a nested Manova to test the intrageneric variations in a same genus. Pairwise multicomparisons tests were also used to assess the differences between other taxa, such as $A$. paaliense and $P$. montalbanensis. Both tests included the coordinates of the first ten axes of the PCA for which the sum met $95 \%$ of the total variation. These data were previously rank transformed since they did not fulfill the required parameters (i.e., normality, homoscedasticity of variances) for such statistical tests (Conover \& Iman, 1981). A phenogram was computed as well by using an UPGMA analysis involving a Euclidian distance matrix calculated from the harmonic coefficients.

\subsection{Incisor enamel microstructure}

Four species were investigated here to complement the Kalthoff's sampling (2006), which already included $A$. atavus, E. dubius, E. gerandianus, and E. infralactorensis. Our samples encompass a French specimen of $A$. atavus, one specimen of $A$. aff. nanus from the Lower Oligocene, two specimens of $A$. cf. huberi and two specimens of $E$. huerzeleri from the Upper Oligocene, also used for the outline analysis. Asian species could not be investigated here.

Small pieces of lower incisor were imbedded in epoxy resin. This resin was grinded and polished to obtain a smooth transverse section of the incisor. About 5 seconds of etching with $\mathrm{HCl} 4 \%$ was necessary to make the enamel details visible. The enamel microstructures was then examined and digitized with a scanning electron microscope at different magnification (x 100 to x 5,000). They were described according to the nomenclature of Koenigswald \& Sander (1997).

\section{RESULTS}

\subsection{Outline analysis}

The first two axes of the PCA represent respectively $30.68 \%$ and $18.64 \%$ of the total variance, while the third represent $15.33 \%$ (Fig. 3). Along the first axis, the shape variation mainly concerns the disto-labial border, which forms an acute angle on the negative side and a right angle on the positive side, and also the prelobe which has a tendency to broaden toward the positive side. On the second component, the length/width ratio mainly varies, that is reflected by a compacted molar on the negative side and a slender one on the positive side. Finally, the particularity of the third axis relies on teeth having an elongated prelobe on one side and compacted teeth with a shorter prelobe on the other side. More generally, outlines of most Atavocricetodon and Eucricetodon species overlap. Specimens of E. jilantaiensis tend to marginalize because 


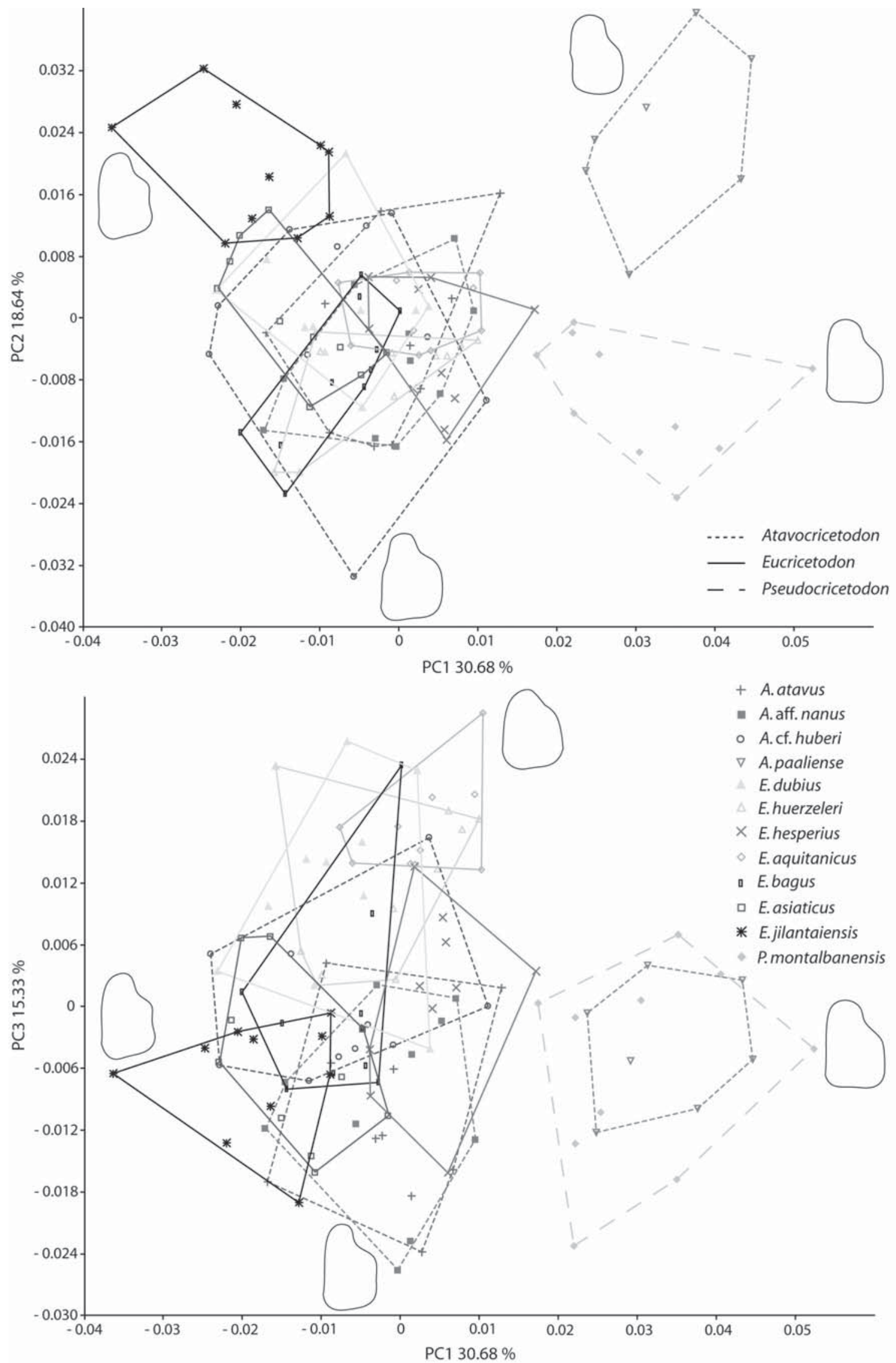

Figure 3. Graphs of the principal component analysis (PCA) realized on the first eight harmonics describing the $\mathrm{M}^{1}$ outline for each species. 
of their strongly slender teeth (axis 2); nonetheless, they present some affinities with $A$. asiaticus. This trend can also be observed in E. aquitanicus, which shows compacted teeth with a short prelobe (axis 3). Outlines of A. paaliense strongly differ from other Atavocricetodon in having slender teeth (axis 2), a broad prelobe and a more quadrate distal shape (axis 1). They are close to $P$. montalbanensis notably on the components 1 and 3, and only their length/width ratio appears distinct (axis 2).

The Manova reveals that there are significant differences between each genus, and also between species within Atavocricetodon and Eucricetodon according to the nested Manova (Table 2a). The only insignificant difference observed concerns $A$. paaliense and $P$. montalbanensis, according to the conservative Bonferroni test (Table 2b).

Four groups are clearly differentiated on the phenogram (Fig. 4). The first one included $P$. montalbanensis and $A$. paaliense, which, although distant, are opposed to other Eucricetodontinae. Two species from Ulantatal, E. asiaticus and $E$. jilantaiensis are gathered. A third geographical heterogenous group encompasses E. aquitanicus, E. bagus and E. huerzeleri. The last group is European and consists of $A$. atavus and $A$. aff. nanus on one side, and of $E$. hesperius, A. cf. huberi, and E. dubius on the other side.

Table 2. a) Results of the Manova and nested Manova realized on the first ten PCA coordinates involving each species clustered by genus (except $P$. montalbanensis; significant difference at $\alpha=0.05$, df: degree of freedom). b) Results of Hotelling's (above the diagonal) and Bonferroni (below the diagonal) pairwise comparisons tests. ${ }^{*}$ means results with or without $A$. paaliense.

\begin{tabular}{lcrc}
\hline a) & df & \multicolumn{1}{c}{$\mathrm{F}$} & \multicolumn{1}{c}{$\mathrm{p}$} \\
\hline Species (Genus) & 99 & 198.230 & $<\mathbf{0 . 0 0 1}$ \\
Species & 11 & 6.251 & $<\mathbf{0 . 0 0 1}$ \\
\hline
\end{tabular}

\begin{tabular}{lcccc}
\hline b) & Atavocricetodon & Eucricetodon & A. paaliense & Pseudocricetodon \\
\hline Atavocricetodon & & $<\mathbf{0 . 0 0 1} *$ & $<\mathbf{0 . 0 0 1}$ & $<\mathbf{0 . 0 0 1} *$ \\
Eucricetodon & $<\mathbf{0 . 0 0 1 *}$ & & $<\mathbf{0 . 0 0 1}$ & $<\mathbf{0 . 0 0 1}$ \\
A. paaliense & $<\mathbf{0 . 0 0 1}$ & $<\mathbf{0 . 0 0 1}$ & & $\mathbf{0 . 0 1 5}$ \\
Pseudocricetodon & $<\mathbf{0 . 0 0 1 *}$ & $<\mathbf{0 . 0 0 1}$ & 0.092 & \\
\hline
\end{tabular}

\subsection{Incisor enamel microstructure}

The specimen of $A$. atavus from Itardies shows an enamel thickness of about $25 \mu \mathrm{m}$ and includes two distinct layers: a portio externa (PE) and a thicker portio interna (PI). The PE is arranged in parallel prism of crystallites characterizing the radial enamel (Fig. 5a). The PI consists in uniserial enamel defined by one layer of prisms decussating and thus appearing as Hunter-Schreger bands (HSB; Fig. 5b). The HSB are obliquely and transversally oriented from the enamel-dentine junction (edj), and include prismparallel interprismatic matrix (IPM). This schmelzmuster corresponds to the type 1 (Fig. 5c), and the overall structure is similar to the investigated specimen of $A$. atavus from Hoogbutsel (Kalthoff, 2000). The enamel microstructures of $A$. aff. nanus (Fig. 5d) and E. huerzeleri (Fig. 5e) are type 1 as well with a relatively thicker PE, while their enamel thickness is about 40 and $60 \mu \mathrm{m}$, respectively. Conversely, the incisor microstructure of both specimens of $A$. cf. huberi (Fig. 5f) is more complex and corresponds to type 8 . The enamel thickness is about $80 \mu \mathrm{m}$. The PE is highly reduced compared to PI, and includes both radial and tangential enamel. The PI consists of longitudinal HSB with prism-parallel IPM and rectangular IPM in the part close to edj.

\section{DISCUSSION}

Early eucricetodontines constitute the simplest forms from a morphological viewpoint, due to their bunodont patterns and their primitive cricetid plan (i.e., without accessory cusp and loph). Despite such shared characters, their global shapes are extremely variable whatever the genus. Therefore, the present outline analysis did not permit to clearly define morphotypes or evolutionary stages. Significant differences exist between dental outlines of Atavocricetodon and Eucricetodon, but according to the PCA they are minor given the overlapping of morphospaces. That can be considered as the result of a non-negligible interspecific (i.e., intrageneric) variation in view of the results of the nested Manova. Dental shape is notably linked to the own evolutionary history of these taxa and it is not strictly correlated to their occlusal morphology.

That is partly expressed by the phenogram. For instance, the Asian E. asiaticus and E. jilantaiensis are sister species (Vianey-Liaud et al., 2011), they have a close dental shape, while they present a primitive and derived dental pattern respectively (e.g., proverse $v s$ retroverse distal lophs on upper molars; Gomes Rodrigues et al., 2012). Similarly, E. aquitanicus, E. bagus and E. huerzeleri, which come from different Eurasian areas, have different ages and different dental morphologies, but they display close dental shape. If $A$. atavus and $A$. aff. nanus as early Atavocricetodon species are grouped together, the Late Oligocene $A$. aff. huberi and E. dubius have comparable shape, even if they do not belong to the same genus. All these observations join the thought of Dienemann (1987) who already argued that the impossibility of finding diagnostic characters for 

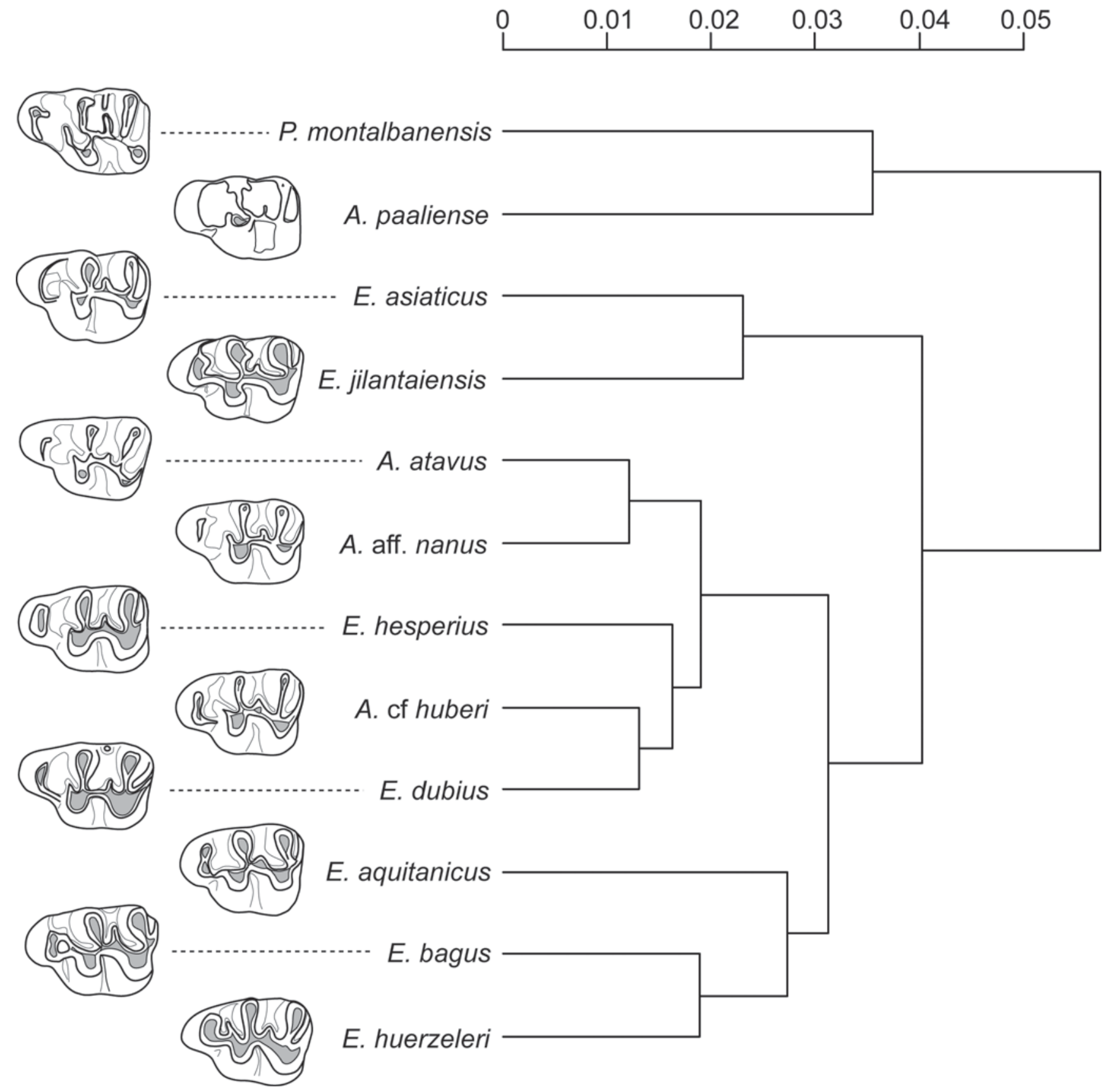

Figure 4. Phenogram of an UPGMA analysis involving a Euclidian distance matrix calculated from the first eight harmonic coefficients, and including left $\mathrm{M}^{1}$ diagrams (not to scale).

Eucricetodon s.l. (i.e., sensus Thaler, 1966), and thus indirectly for Atavocricetodon, relies on the fact it is a long-term genus having a vast shape variation, which covers numerous evolutionary stages.

Apart from these observations, the case of $A$. paaliense appears directly linked to the Pseudocricetodontinae, whose stem species have close dental morphologies with respect to Eucricetodontinae that could explain the confusion. This species has a pseudocricetodontine-like shape, in being slender and in having a broad prelobe, as Pseudocricetodon nawabi Marivaux et al., 1999, the only other muroid found in the same locality (Paali Nala $\mathrm{C}_{2}$, Bugti Hills, Pakistan, Lower Oligocene; Marivaux et al., 1999). However, A. paaliense displays much more affinities with another Pseudocricetodontinae, Kerosinia variabilis Unay-Bayraktar, 1989, a Turkish species from late Early Oligocene sites. In addition of being small, both taxa present a central mure and an endomesostyle on upper molars, a frequently complete protolophule I on $\mathrm{M}^{1}$, a weak lingual cingulum on $\mathrm{M}^{2}$, similar lower molars with a 

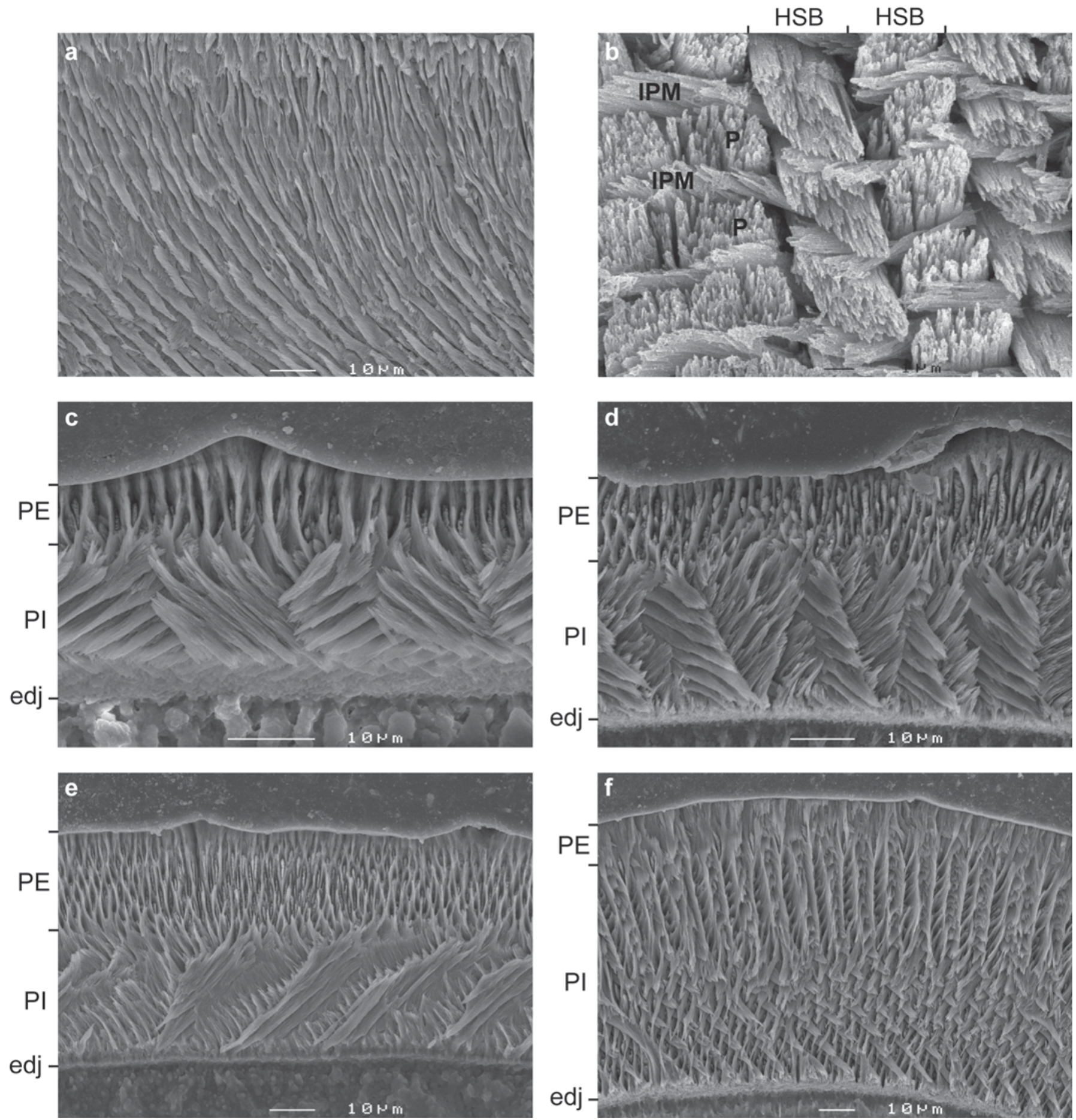

Figure 5. SEM photographs of incisor enamel microstructures. a) radial enamel; b) uniserial enamel; c) Atavocricetodon atavus (ITD53, type 1); d) Atavocricetodon aff. nanus (CAV-701, type 1); e) Eucricetodon huerzeleri (MPF, type 1); f) Atavocricetodon cf. huberi (Bel1-1, type 8). P: prism, IPM: interprismatic matrix, HSB: Hunter-Schreger bands, PE: portio externa, PI: portio interna, edj: enamel-dentine junction. 
complete anterolophulid on $\mathrm{M}_{1}$, a metalophulid II reaching the top of the metaconid, a mesolophid short and slightly twinned to absent, and a strong anterolophid on $\mathrm{M}_{2}$ (UnayBayraktar, 1989). From these results, A. paaliense likely belongs to Kerosinia. This example once again underscores the lack of discrete characters defining Atavocricetodon, and the resulting misinterpretations.

More generally, the species attributed to Atavocricetodon have a small size as Eocene genera. If this character is specific to this genus, it cannot represent a diagnostic character, and moreover their particularity is not exclusive among Eucricetodontinae. For instance, the Asian species E. bagus and E. youngi have similar size range. If Atavocricetodon could also present the practical advantage of forming a morpho-subgenus of Eucricetodon (according to de Bruijn et al., 2003) comprising all small and primitive European Eucricetodontinae, the taxonomic status (genus or subgenus) still remain hard to distinguish, and there is no evidence that a species is more related to Atavocricetodon than to Eucricetodon. Nor it is question of a specific stratigraphic range (i.e., "chronogenus") because there was still Atavocricetodon species in Europe, such as A. huberi, when Eucricetodon appeared during the Late Oligocene (Vianey-Liaud, 1972; Comte, 1985).

Since the last decade (Kalthoff, 2006), the enamel microstructure of lower incisors was assumed as the only one discrete character which could clearly differentiate Atavocricetodon from Eucricetodon species. Our results do not support this hypothesis, and suggest this character could convergently evolve in the diverse group or lineages of Atavocricetodon and Eucricetodon. Thus, first Atavocricetodon, such as A. atavus and A. aff. nanus, displays a primitive enamel (type 1), while surprisingly, the more recent one, $A$. cf. huberi, have a highly derived enamel which is convergent to Pseudocricetodontinae (e.g., Pseudocricetodon, Heterocricetodon; type 8, Kalthoff, 2006). Similarly, one of the oldest European Eucricetodon, E. huerzeleri, has a primitive schmelzmuster (type 1), while the more recent species (e.g., E. dubius) have slightly more complex microstructure (type 4). As a result, it is impossible to use this character in the definition of both genera, faced to such a microstructural variability.

If the alpha taxonomy of extinct forms is not an easy task for many reasons, especially as regards to rodents (see Vianey-Liaud et al., 2011), defining a higherlevel taxon implies other matters frequently challenged by phylogenetical studies. It can be assumed that Atavocricetodon species, as A. atavus for some European species, give rise to many Eucricetodon lineages, like those of E. collatus and E. huerzeleri (Comte, 1985). This is notably supported by the incisor enamel schmelzmuster of this latter species (type 1) shared with most Atavocricetodon species. In this way, retaining a paraphyletic genus (i.e., Atavocricetodon) would also mean that Eucricetodon has to be now regarded as a polyphyletic genus. Consequently, there is no obvious reason, even pragmatical, to keep Atavocricetodon as a genus or even a subgenus. As far as we know, the more accurate definition of Eucricetodon s.l. was given by Vianey-liaud (1972). Nonetheless, it clearly appears that Eucricetodon involves a very high amount of species from different area and with a wide range of dental morphologies (cf. Dienemann, 1987), which represent various lineages and most probably different genera still undefined. More materials, including skulls necessary to notably investigate the evolution of infraorbital foramina (Vianey-Liaud, 1974) and others morphological items are crucial to try to definitely clarify these longstanding issues.

\section{ACKNOWLEDGEMENTS}

Many thanks go to B. Marandat and J.-P. Aguilar from the Institut des Sciences de l'Evolution de Montpellier (ISEM-UM2), and to the curators L. Jin and C. Jing (IVPP) who permitted the study of fossil specimens. We are grateful to R. Tabuce (ISEM-UM2), S. Agret (Morphometrical platform, ISEM-UM2) as well as Lionel Hautier (University of Cambridge, UK) and Julia Wöger (Wien, Austria) for their help during data acquisition. We also strongly thank D. Kalthoff (Swedish Museum of Natural History, Stockholm, Sweden) for her interesting discussions concerning incisor enamel microstructure. We also acknowledge M. Freudenthal (University of Granada, Spain) and the anonymous reviewer who have permitted to improve the quality of our paper. This paper is dedicated to the memory of Nieves López Martínez which greatly contributed to the improvement of this study. Publication ISEM 2012-164.

\section{REFERENCES}

Agusti, J. \& Arbiol, S. 1989. Nouvelles espèces de Rongeurs (Mammalia) dans l'Oligocène supérieur du Bassin de l'Ebre (NE de l'Espagne). Geobios, 22, 265-275.

Comte, B. 1985. Eléments nouveaux sur l'évolution des genres Eucricetodon et Pseudocricetodon (Eucricetodontinae, Rodentia, Mammalia) de l'Oligocène d'Europe Occidentale. Paleovertebrata Montpellier, 15, 1-69.

Conover, W.J. \& Iman, R.L. 1981. Rank transformation as a bridge between parametric and nonparametric statistics. American Statistician, 35, 124-129.

Crampton, J.S. 1995. Elliptic Fourier shape analysis of fossil bivalves: some practical considerations. Lethaia, 28, 179-186.

de Bruijn, H., Unay, E., Saraç, G. \& Yilmaz, A. 2003. A rodent assemblage from the Eo/Oligocene boundary interval near Süngülü, Lesser Caucasus, Turkey. Coloquios de Paleontología, 1, 47-76. 
Dienemann, A. 1987. Die Gattungen Eucricetodon und Pseudocricetodon (Rodentia, Mammalia) aus dem Oligozän Süddeutschlands. Abhandlungen/Bayerische Akademie der Wissenchaften, Mathematisch-Naturwissenschaftliche Klasse, 165, 158 p.

Ferson, S., Rohlf, F.J. \& Koehn, R.K. 1985. Measuring shape variation of two-dimensional outlines. Systematic Biology, 34, 59-68.

Freudenthal, M. 1996. The Early Oligocene rodent fauna of Olalla 4A (Teruel, Spain). Scripta Geologica, 112, 1-67.

Gomes Rodrigues, H., Marivaux, L. \& Vianey-Liaud, M. 2010. Phylogeny and systematic revision of Eocene Cricetidae (Rodentia, Mammalia) from Central and East Asia: on the origin of cricetid rodents. Journal of Zoological Systematics and Evolutionary Research, 48, 259-268.

Gomes Rodrigues, H., Marivaux, L. \& Vianey-Liaud, M. 2012. The Cricetidae (Rodentia, Mammalia) from the Ulantatal area (Inner Mongolia, China): new data concerning the evolution of Asian cricetids during Oligocene. Journal of Asian Earth Sciences, 56, 160-179.

Hugueney, M. 1999. Genera Eucricetodon and Pseudocricetodon. In: The Miocene Land Mammals of Europe (eds. Rössner, G. \& Heissig, K.). Friedrich Pfeil, Munich, 347-358.

Kalthoff, D. 2000. Die Schmelzmikrostruktur in den Incisiven der hamsterartigen Nagetiere und anderer Myomorpha (Rodentia, Mammalia). Palaeontographica Abt. A, 259, 1-193.

Kalthoff, D. 2006. Incisor enamel microstructure and its implications to the systematics of Eurasian Oligocene and lower Miocene hamsters. Palaeontographica Abt. A, 277, 67-80.

Koenigswald, W.v. \& Kalthoff, D.C. 2007. The enamel microstructure of molars and incisors of Paleogene and early Neogene rodents from Mongolia. In: OligoceneMiocene Vertebrates from the Valley of Lakes (Central Mongolia): Morphology, phylogenetic and stratigraphic implications (ed. Daxner-Höck, G.). Annalen des Naturhistorischen Museums in Wien, 219-312.

Koenigswald, W.v. \& Sander, P.M. 1997. Glossary of terms used for enamel microstructures. In: Tooth Enamel Microstructure (eds. Koenigswald, W.V. \& Sander, P.M.). Balkema, Rotterdam, 267-280.
Kuhl, F.P. \& Giardina, C.R. 1982. Elliptic Fourier features of a closed contour. Computer Graphics and Image Processing, 18, 259-278.

Lazzari, V., Charles, C., Tafforeau, P., Vianey-Liaud, M., Aguilar, J.-P., Jaeger, J.-J., Michaux, J. \& Viriot, L. 2008. Mosaic Convergence of Rodent Dentitions. Plos One, 3 , $1-13$.

Marivaux, L., Vianey-Liaud, M. \& Welcomme, J.-L. 1999. Première découverte de Cricetidae (Rodentia, Mammalia) oligocènes dans le synclinal sud de Gandoï (Bugti Hills, Balouchistan, Pakistan). Comptes Rendus de l'Académie des Sciences de Paris, 329, 839-844.

Musser, G.G. \& Carleton, M.D. 2005. Superfamily Muroidea. In: Mammal Species of the World. A Taxonomic and Geographic Reference (3rd ed) (eds. Wilson, D.E. \& Reeder, D.M.). Johns Hopkins University Press, Baltimore, 894-1531.

Renaud, S., Michaux, J., Jaeger, J.-J. \& Auffray, J.-C. 1996. Fourier analysis applied to Stephanomys (Rodentia, Muridae) molars: non progressive evolutionary pattern in gradual lineage. Paleobiology, 22, 255-265.

Thaler, L. 1966. Les rongeurs fossiles du Bas-Languedoc dans leurs rapports avec l'histoire des faunes et la stratigraphie du Tertiaire d'Europe. Mémoires du Muséum National d'Histoire Naturelle, Paris, Paris.

Unay-Bayraktar, E. 1989. Rodents from the Middle Oligocene of Turkish Thrace. Utrecht micropaleontological bulletins. Special publication, Utrecht, 5, 1-120.

Vianey-Liaud, M. 1972. Contribution à l'étude des Cricétidés Oligocènes d'Europe occidentale. Palaeovertebrata Montpellier, 5, 1-44.

Vianey-Liaud, M. 1974. L'anatomie crânienne des genres Eucricetodon et Pseudocricetodon (Cricetidae, Rodentia, Mammalia): essai de systématique des Cricétidés Oligocènes d'Europe Occidentale. Annales de Géologie Méditerranéenne, Université de Provence, 1, 111-131.

Vianey-Liaud, M., Gomes Rodrigues, H. \& Michaux, J. 2011. The Linnaean binomial nomenclature in palaeontology: its use in the case of rodents (Mammalia, Rodentia). Comptes Rendus Palevol, 10, 117-131.

Wang, B. 2007. Late Eocene cricetids (Rodentia, Mammalia) from Nei Mongol, China. Vertebrata Palasiatica, 45, 195-212.

Wood, A.E. \& Wilson, R.W. 1936. A suggested nomenclature of the cheek teeth of rodents. Journal of Paleontology, 10,388 . 
